\title{
Value of Multiplatform Molecular Profiling (MMP) of Tumors in Clinical Practice
}

\author{
Ofer Purim ${ }^{1 *}$, Aron Popovtzer ${ }^{2}$, Ron Epelbaum ${ }^{3}$ \\ 'Oncology Institute, Assuta Ashdod Academic Hospital, Ashdod, Israel \\ ${ }^{2}$ Institute of Oncology, Davidoff Center, Rabin Medical Center, Petah Tikva, Israel, and Sackler Faculty of Medicine, Tel Aviv University, Tel Aviv, Israel \\ ${ }^{3}$ Department of Oncology, Rambam Health Care Campus, Haifa, Israel
}

\section{Article Info}

\section{Article Notes}

Received: August 06, 2018

Accepted: August 27, 2018

\section{${ }^{*}$ Correspondence:}

Dr. Ofer Purim, Oncology Institute, Assuta Ashdod Academic Hospital, Harefua St. 7 Ashdod, 7747629, Israel; Telephone No: +972-72-3398120; Fax No: +972-72-3398961; Email: oferp@assuta.co.il.

(c) 2018 Purim O. This article is distributed under the terms of the Creative Commons Attribution 4.0 International License.

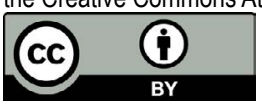

\section{Keywords:}

Biomarker

Chemotherapy

Multiplatform Molecular Profiling

Overall Survival

Progression-Free Survival

Targeted Therapy

\section{Abstract}

In the last 20 years, cancer treatment has witnessed a paradigm shift with the advent of modern targeted therapies. Still, at present, targeted therapies, despite being very effective, are only relevant for a minority of patients, whereas the majority of patients are still being offered cytotoxic drugs. The goal of this mini-review is to describe the clinical utility of tumor multi-panel molecular profiling (MMP) to guide treatment decisions (primarily chemotherapies but also targeted therapies) in patients with solid tumors and the evidence supporting this approach, focusing on the Caris Molecular Intelligence (CMI) MMP. The evidence suggests that MMP is a practical, implementable tool that can be used to personalize treatment (including that of chemotherapies), increasing the likelihood of response and sparing patients from unnecessary toxicity associated with ineffective therapies. MMP provides the ability to offer therapy to patients in later lines, particularly for those who have already failed multiple lines of therapy and exhausted the standard therapy options (by suggesting therapies which may be used off-label). Furthermore, the evidence indicates that MMP-guided therapy favorably impacts both progression-free survival and overall survival. As the current data consist of mainly retrospective studies, prospective trials are warranted to strengthen the evidence.

\section{Introduction}

The approach to cancer treatment evolved dramatically with the introduction of modern targeted therapies approximately 20 years ago ${ }^{1}$. Molecular profiling of tumors in order to facilitate selection of patients for targeted therapy has evolved in parallel to the advances in the development of the targeted agents. At present, targeted therapies, despite their effectiveness, are only relevant for a minority of patients, whereas the majority of patients are still being offered cytotoxic drugs.

This mini-review describes the current experience with molecular profiling focusing on one multiplatform molecular profiling (MMP) approach, the Caris Molecular Intelligence platform (CMI; Caris Life Sciences, Irving, Texas).

\section{MMP for Selecting Therapies}

Biomarker-driven selection is necessary for certain targeted therapies and thus constitutes the standard-of-care (SOC) in these cases. For example, trastuzumab is FDA-approved for HER2-positive breast cancer (as determined by HER2-testing using FDA-approved companion tests) and anti-EGFR antibodies are FDA-approved for RAS wild-type metastatic colorectal cancer (as determined by FDA-approved companion test) ${ }^{2,3}$. Currently, MMP is recommended for some patients by the National 
Comprehensive Cancer Network (NCCN) (e.g., broad profiling for patients with non-small cell lung cancer [NSCLC]) and not used widely for selecting cytotoxic chemotherapies.

Chemotherapies are associated with a broad range of response rates. Whereas in certain cases such as testicular cancer, the overall response rate to chemotherapy can be very high ( $>90 \%$ for good-risk metastatic disease), in other tumor types, for example, pancreatic cancer, the response rate is modest (up to approximately 30\% in first-line treatment for metastatic disease $)^{4-7}$. Furthermore, analysis of an advanced cancer population with diverse tumor types demonstrated a statistically significant decrease in progression-free survival (PFS) with each successive line of chemotherapy ${ }^{8}$.

Targeted therapies, when properly selected, can be very effective due to their specificity. For example, trastuzumab, one of the first modern targeted therapies, was shown to provide significant clinical benefit in the metastatic as well as in the adjuvant breast cancer setting ${ }^{9-11}$. Interestingly, analysis of a large database of patients who participated in phase I clinical trials demonstrated that out of 2,027 patients, $31 \%$ of those in chemotherapy trials had progressive disease (PD) at first imaging evaluation vs 61\% in targeted therapies trials, suggesting that chemotherapy may be more effective than targeted therapy if the latter is not well-targeted ${ }^{12}$. Furthermore, in standard genomic sequencing, clear and druggable mutations are not found in many cases.

Therefore, optimizing the selection of chemotherapy using biomarker-driven guidance (instead of empiric selection) could improve response rate, extend PFS, and potentially extend overall survival (OS). Importantly, biomarker-driven guidance could also help patients avoid the toxicity associated with a chemotherapy from which they are not expected to benefit. Additionally, in patients who fail multiple lines of therapy and who exhaust the standard treatments (which is often the case in patients with rare types of cancer), biomarker-driven selection could provide insights into potentially off-label use of commercially available chemotherapies.

\section{Tumor Profiling Methodologies}

The arsenal of methodologies used in tumor profiling evolved over time. Immunohistochemistry (IHC), which detects proteins in the tissue sample by using specific antibodies, remains a key methodology for detecting biomarkers relevant for chemotherapy and endocrine therapy selection and for several important biomarkers assessing the potential of benefit from immune-checkpointinhibitors (e.g., PD-L1, mismatch repair [MMR] proteins); whereas, next generation sequencing (NGS), for example, may be useful for detecting driver mutations predictive of response to specific targeted therapies.

The MMP approach acknowledges that the methodology used for profiling should be appropriate for the predictive association and therefore utilizes multiple platforms for detecting proteins, RNA expression levels, DNA mutations, copy number variations, etc. Table 1 summarizes some of

Table 1: Summary of biomarkers tested by IHC and the drugs for which an association has been established (based on the CMI platform as of April 2018; A. Voss, personal communication).

\begin{tabular}{|c|c|c|}
\hline Biomarker & Drug(s) & Comments \\
\hline \multirow{2}{*}{ PD-L1 } & avelumab & Association is limited to Merkel cells \\
\hline & atezolizumab, nivolumab, pembrolizumab & Association in bladder, kidney, melanoma, and NSCLC only \\
\hline TS & capecitabine, fluorouracil, pemetrexed & \\
\hline ERCC1 & carboplatin, cisplatin, oxaliplatin & \\
\hline \multirow{3}{*}{ PTEN } & cetuximab, panitumumab & Association in CRC only \\
\hline & erlotinib, gefitinib & Association in NSCLC only \\
\hline & trastuzumab & Association in breast cancer only \\
\hline MGMT & decarbazine, temozolomide & \\
\hline TUBB3 & docetaxel, paclitaxel, nab-paclitaxel & \\
\hline TOPO1 & irinotecan, topotecan & For topotecan association excludes breast, CRC, and NSCLC \\
\hline TOP2A & doxorubicin, liposomal doxorubicin, epirubicin & \\
\hline \multirow{2}{*}{ AR } & enzalutamide, bicalutamide & Association in TNBC only \\
\hline & hormone therapy ${ }^{a}$ & \\
\hline \multirow[b]{2}{*}{ ER } & everolimus, temsirolimus, palbociclib, ridociclib & Association in breast cancer only \\
\hline & $\begin{array}{l}\text { exemestane+everolimus, fulvestrant, , } \\
\text { palbocilib combination therapy, hormone therapy }{ }^{\text {a }}\end{array}$ & \\
\hline PR & hormone therapy ${ }^{a}$ & \\
\hline \multirow{2}{*}{ HER2/Neu } & palbociclib, ridociclib & Association in breast cancer only \\
\hline & trastuzumab & \\
\hline
\end{tabular}

a hormone therapies may include tamoxifen, toremifene, fulvestrant, letrozole, anastrazole, exemestane, megestrol acetate, leuprolide, goserelin, bicalutamide, flutamide, abiraterone, enzalutamide, triptorelin, abarelix, degarelix.

Note: $A R=$ androgen receptor, $C R C=$ colorectal cancer, $E R=$ estrogen receptor, $I H C=$ immunohistochemistry, NSCLC $=$ non-small cell lung cancer, $\mathrm{PR}=$ progesterone receptor, $\mathrm{TNBC}=$ triple-negative breast cancer. 
the biomarkers tested by IHC in the CMI MMP approach and the drugs associated with these biomarkers (based on the CMI platform as of 4/2018; A. Voss, personal communication).

\section{Studies Exploring the Clinical Utility of MMP}

Investigating the clinical benefit associated with MMPguided treatment is challenging with respect to study design, as conventional study designs/endpoints would require an unrealistic number of patients and long follow up. Thus far, 2 approaches have been used to assess the CMI MMP. The initial pivotal study describing the MMP benefit was published by Von Hoff and colleagues in $2010^{13}$, and is schematically summarized in Figure 1.This prospective multi-center single-arm study, which included 86 patients with a variety of refractory solid tumors who underwent MMP, employed a novel endpoint, the PFS ratio, which became the standard endpoint in subsequent studies. Its underlying notion was that each tumor has a unique molecular profile; therefore, each patient served as their own control, and the PFS on MMP-guided treatment was compared to that on the prior line of treatment (pre-MMP). PFS ratio $\geq 1.3$ was defined as clinical benefit, and the null hypothesis was that $\leq 15 \%$ of the patient population would demonstrate such a ratio ${ }^{13}$. In the Von Hoff study, of the 86 patients who underwent tumor MMP, 66 received MMP-guided therapy, of whom $27 \%$ experienced clinical benefit as defined above. One-sided one-sample, nonparametric test yielded $P=0.007$, therefore rejecting the null hypothesis and demonstrating the potential utility of the MMP approach ${ }^{13}$.

Following this pivotal study, the CMI MMP approach was incorporated into clinical practice, and reports describing additional analyses focusing on the utility of this approach were published/presented. Table 2 summarizes the Von Hoff study as well as 10 subsequent studies conducted worldwide (US, Austria, Australia, Israel, Lebanon, and Egypt ${ }^{13-23}$. Some of these studies investigated advanced disease in specific tumor types such as gastric/esophageal ${ }^{14}$, pancreatic/pancreaticobiliary ${ }^{15,16}$, breast $\mathrm{t}^{17}$, and salivary glands cancer ${ }^{18}$, whereas other studies included a variety of refractory solid cancers including rare tumors ${ }^{19-23}$. Overall, 345 patients were evaluable in the 11 studies combined. Three studies from the US, Australia, and Israel reported on changes in treatment decisions between empiric selection (pre-MMP) and MMP-guided selection ${ }^{15,17,19}$. The change rate was high and ranged from $74 \%$ to $100 \%$ of cases $^{17,19,21}$. All the studies reported on clinical benefit. In 7 studies (involving a total of 218 evaluable patients) the PFS ratio endpoint was used, and the clinical benefit rate ranged from $27 \%$ to $59.5 \%{ }^{13-15,17,19,22,23}$. In the remaining 4 studies (involving a total of 127 evaluable patients), other outcome measures were used such as response rate (complete response [CR] rate plus partial response [PR] rate), disease control rate (CR plus PR plus stable disease [SD] rate), and 1-year survival rate. MMP-guided treatment was associated with clinical benefit in a considerable proportion of patients (20\%-73\%) in these 4 studies as well ${ }^{16,18,20,21}$. Although the studies were consistent in demonstrating that MMP provides relevant biomarker information, modifies treatment decisions, and facilitates extension of $\mathrm{PFS}^{13-23}$, they were limited by relatively modest cohort sizes, and some also by their retrospective design.

In addition to the above mentioned studies, another innovative design was employed by Marshall and colleagues, in which time to next treatment (TNT) was used

86 patients with refractory cancer undergoing MMP

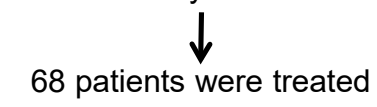

66 received MMP-guided treatment

(18 breast, 11 CRC, 5 ovarian, 32 others)

PFS ratio (PFS on MMP-guided treatment/PFS on

prior therapy) was evaluated

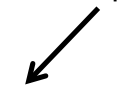

18 patients $(27 \%)$ had PFS ratio $\geq 1.3$ (8 breast, 4 CRC, 1 ovarian, 5 others)

Median PFS in these 18 patients, 2.9 (range, 1.3-8.2) months
Overall response rate, $6 / 66(9 \%)$ including:

$1 \mathrm{CR}$ (breast) and $5 \mathrm{PR}$

(2 breast, 1 rectal, 1 ovarian, 1 NSCLC)

Figure 1: Summary of the Von Hoff et al pivotal study ${ }^{13} . C R=$ complete response, $C R C=$ colorectal cancer, $M M P=$ multiplatform molecular profiling, NSCLC $=$ non-small cell lung cancer, $\mathrm{PFS}=$ progression-free survival, $\mathrm{PR}=$ partial response. 
Table 2: Summary of studies investigating the role of MMP in patients with refractory/metastatic cancer

\begin{tabular}{|c|c|c|c|c|c|c|c|c|c|c|c|}
\hline Study (ref) & Study type & $\begin{array}{c}\text { Country of } \\
\text { study }\end{array}$ & Indications & $\begin{array}{c}\text { Methodologies used for } \\
\text { profiling }\end{array}$ & $\begin{array}{l}\text { Patients } \\
\text { profiled }\end{array}$ & $\begin{array}{l}\text { Patients } \\
\text { treated }\end{array}$ & $\begin{array}{l}\text { Patients } \\
\text { treated } \\
\text { based on } \\
\text { profiling } \\
\text { results }^{\mathrm{a}}\end{array}$ & $\begin{array}{c}\text { Patients } \\
\text { evaluable } \\
\text { for clinical } \\
\text { benefit }\end{array}$ & $\begin{array}{l}\text { Measure } \\
\text { of benefit }\end{array}$ & $\begin{array}{c}\text { Clinical } \\
\text { benefit } \\
\text { rate } \\
\text { (out of } \\
\text { evaluable } \\
\text { patients) }\end{array}$ & $\begin{array}{l}\text { P vs the null } \\
\text { hypothesis } \\
\text { (when } \\
\text { using the } \\
\text { PFS ratio } \\
\text { endpoint) }\end{array}$ \\
\hline $\begin{array}{l}\text { Von Hoff et } \\
\text { al., } 2010^{13}\end{array}$ & $\begin{array}{l}\text { Prospective, } \\
\text { single-arm }\end{array}$ & US & $\begin{array}{l}\text { Refractory/ } \\
\text { metastatic solid } \\
\text { tumors }\end{array}$ & IHC, ISH, DNAMA & 86 & 68 & 66 & 66 & $\begin{array}{c}\text { PFS } \\
\text { ratio } \geq 1.3\end{array}$ & $27 \%$ & 0.007 \\
\hline $\begin{array}{l}\text { Jameson et } \\
\text { al., } 2014^{17}\end{array}$ & $\begin{array}{l}\text { Prospective, } \\
\text { single-arm }\end{array}$ & US & $\begin{array}{c}\text { Refractory/ } \\
\text { metastatic breast } \\
\text { cancer }\end{array}$ & $\begin{array}{c}\text { IHC, ISH, DNAMA, } \\
\text { RRPA }^{c}\end{array}$ & 28 & 25 & 25 & 25 & $\begin{array}{c}\text { PFS } \\
\text { ratio } \geq 1.3\end{array}$ & $44 \%$ & NA \\
\hline $\begin{array}{l}\text { El Ahmadi et } \\
\text { al., } 2015^{21 *}\end{array}$ & $\begin{array}{l}\text { Retrospective } \\
\text { cohort study }\end{array}$ & Lebanon & $\begin{array}{l}\text { Refractory/ } \\
\text { metastatic solid } \\
\text { tumors }\end{array}$ & IHC, ISH, NGS & 73 & 69 & 69 & 59 & $\begin{array}{c}\mathrm{CR} / \mathrm{PR} \\
\mathrm{CR} / \mathrm{PR} / \mathrm{SD}\end{array}$ & $\begin{array}{l}34 \% \\
69 \% \\
\end{array}$ & NA \\
\hline $\begin{array}{l}\text { Epelbaum et } \\
\text { al., } 2015^{15}\end{array}$ & $\begin{array}{l}\text { Retrospective } \\
\text { cohort study }\end{array}$ & Israel & $\begin{array}{c}\text { Advanced } \\
\text { pancreaticobiliary } \\
\text { cancer }\end{array}$ & $\begin{array}{c}\text { IHC, ISH, DNAMA, } \\
\text { Sanger sequencing, NGS }\end{array}$ & 55 & 30 & 30 & 24 & $\begin{array}{c}\text { PFS } \\
\text { ratio } \geq 1.3\end{array}$ & $38 \%$ & 0.0015 \\
\hline $\begin{array}{l}\text { Popovtzer et } \\
\text { al., } 2015^{18}\end{array}$ & $\begin{array}{l}\text { Retrospective } \\
\text { cohort study }\end{array}$ & Israel & $\begin{array}{c}\text { Metastatic salivary } \\
\text { gland cancer }\end{array}$ & $\begin{array}{l}\text { IHC, ISH, DNAMA, } \\
\text { Sanger sequencing }\end{array}$ & 14 & 11 & 11 & 11 & $\begin{array}{c}\mathrm{CR} / \mathrm{PR} \\
\mathrm{CR} / \mathrm{PR} / \mathrm{SD}\end{array}$ & $\begin{array}{l}36 \% \\
73 \% \\
\end{array}$ & NA \\
\hline $\begin{array}{l}\text { Dean et al., } \\
2016^{19}\end{array}$ & $\begin{array}{l}\text { Prospective } \\
\text { cohort study }\end{array}$ & Australia & $\begin{array}{c}\text { Refractory/ } \\
\text { metastatic solid } \\
\text { tumors (including } \\
\text { rare tumors) }\end{array}$ & $\begin{array}{c}\text { IHC, ISH, qPCR, Sanger } \\
\text { sequencing }\end{array}$ & NS & 54 & 54 & 37 & $\begin{array}{c}\text { PFS } \\
\text { ratio } \geq 1.3\end{array}$ & $59.5 \%$ & $<0.0001$ \\
\hline $\begin{array}{l}\text { Chahine et } \\
\text { al., } 2016^{22 *}\end{array}$ & $\begin{array}{l}\text { Prospective } \\
\text { cohort study }\end{array}$ & Lebanon & $\begin{array}{l}\text { Advanced/ } \\
\text { metastatic solid } \\
\text { tumors }\end{array}$ & IHC, ISH, sequencing & 34 & NS & 23 & 23 & $\begin{array}{c}\text { PFS } \\
\text { ratio } \geq 1.3\end{array}$ & $57 \%$ & NA \\
\hline $\begin{array}{l}\text { Seeber et al, } \\
2016^{23}\end{array}$ & $\begin{array}{l}\text { Prospective } \\
\text { cohort study }\end{array}$ & Austria & $\begin{array}{l}\text { Refractory/ } \\
\text { metastatic solid } \\
\text { tumors }\end{array}$ & IHC, ISH, NGS & 50 & $40^{d}$ & 19 & 19 & $\begin{array}{c}\mathrm{PFS} \\
\text { ratio } \geq 1.3\end{array}$ & $42 \%$ & NA \\
\hline $\begin{array}{l}\text { El Nahas et } \\
\text { al., } 2017^{20 *}\end{array}$ & $\begin{array}{l}\text { Prospective } \\
\text { cohort study }\end{array}$ & Egypt & $\begin{array}{l}\text { Refractory/ } \\
\text { metastatic solid } \\
\text { tumors }\end{array}$ & IHC, ISH, NGS & 37 & 32 & 30 & $22^{\mathrm{e}}$ & $\begin{array}{c}\mathrm{CR} / \mathrm{PR} \\
\mathrm{CR} / \mathrm{PR} / \mathrm{SD}^{\mathrm{f}}\end{array}$ & $\begin{array}{l}27 \% \\
68 \% \\
\end{array}$ & NA \\
\hline $\begin{array}{l}\text { Ramanathan } \\
\text { et al., } 2017^{16}\end{array}$ & $\begin{array}{l}\text { Prospective } \\
\text { phase } 2 \text { study }\end{array}$ & US & $\begin{array}{c}\text { Refractory/ } \\
\text { metastatic } \\
\text { pancreatic cancer }\end{array}$ & $\begin{array}{c}\text { IHC, ISH, Sanger } \\
\text { sequencing, DNAMA, } \\
\text { flow cytometery, and } \\
\text { aCGH }^{\mathrm{g}}\end{array}$ & 40 & NS & 35 & 35 & $\begin{array}{l}\text { 1-year } \\
\text { survival }\end{array}$ & $20 \%$ & NA \\
\hline $\begin{array}{l}\text { Purim et al., } \\
2018^{14}\end{array}$ & $\begin{array}{l}\text { Retrospective } \\
\text { cohort study }\end{array}$ & Israel & $\begin{array}{c}\text { Metastatic gastric } \\
\text { or esophageal } \\
\text { cancer }\end{array}$ & $\begin{array}{c}\text { IHC, ISH, DNAMA, } \\
\text { Sanger sequencing, NGS }\end{array}$ & 46 & 28 & 27 & $24^{\mathrm{h}}$ & $\begin{array}{c}\text { PFS } \\
\text { ratio } \geq 1.3\end{array}$ & $29 \%$ & 0.019 \\
\hline
\end{tabular}

Note: aCGH = array comparative genomic hybridization, $\mathrm{CR}=$ complete response, DNAMA = DNA microarray, $I H C=$ immunohistochemistry, $I S H=$ in-situ hybridization, $\mathrm{NGS}=$ next-generation sequencing, NS = not specified, RRPA = reverse phase protein microarray, $P R=$ partial response, qPCR = quantitative polymerase chain reaction, $\mathrm{SD}=$ stable disease

*Conference presentation. Publication in a peer-reviewed journal is pending.

an the first line after MMP

${ }^{b}$ The null hypothesis as defined by the Von Hoff study (that $\leq 15 \%$ of the patient population would have PFS ratio of $\geq 1.3$ ). ${ }^{15}$

'Performed by the Center for Applied Proteomics and Molecular Medicine.

In 2 no actionable target was detected, 10 died before starting the MMP-guided treatment, and for 19, MMP-guided treatment awaited at the time of the published report.

'The PFS ratio $\geq 1.3$ enpoint could only be evaluated in 10 patients of whom 4 experienced PFS ratio $\geq 1.3$.

fThis disease control rate includes 2 patients with mixed response and 1 patient with transient response.

${ }^{g}$ DNAMA was performed by the John Hopkins University and flow cytometry and aCGH were performed by the Translational Genomics Research Institute.

${ }^{\mathrm{h}}$ The analysis explored the ratio between the longest PFS after profiling (in any line) compared to the last PFS pre-profiling in all 28 treated patients.

as a surrogate outcome measure ${ }^{24}$. This study included 4,729 unselected patients (heterogeneous in tumor type, stage, and line of therapy) who underwent MMP. Treatment data were obtained retrospectively and patients were considered to have MMP-aligned treatment when the treatment was in line with the biomarker findings, and non-MMP aligned when they were not. The results revealed a statistically significant improvement in TNT between the MMP-aligned $(n=3,011)$ and the non-MMP aligned $(n=1,718)$ cohorts (median TNT of 248 vs 215 days; hazard ratio [HR], 0.85; 95\% confidence interval [CI], 0.78-0.93; $P<0.001$ ). OS, which was evaluable in 505 and 447 patients in the MMP-aligned and non-MMP aligned cohorts, respectively, was also favorably impacted (median OS of 1,069 vs 686 days; HR, 0.69; 95\% CI, 0.56$0.84 ; P<0.001)^{24}$.

Another investigational approach to explore the MMP benefit also used the distinction between MMP-aligned and non-MMP aligned cohorts and applied it to analyze 
OS in patients enrolled into the Caris registry which was established in 2008. This study by Spetzler and colleagues ${ }^{25}$ showed a significant OS increase in the MMP-aligned $(\mathrm{n}=534)$ vs the non-MMP aligned $(\mathrm{n}=493)$ cohorts (median OS of 1,068 vs 646 days; HR, $0.68 ; P=0.001$ ). They also showed that patients in the MMP-aligned cohort received less lines of treatments overall (post-profiling) compared to those in the non-MMP aligned cohort (median of $3.2 \mathrm{vs}$ 4.2 therapies) $)^{25}$.

\section{Cumulative Clinical Experience with MMP}

As of June 2018, the CMI MMP has been used worldwide in $>150,000$ patients across tumor types (Figure 2, A. Voss, personal communication). The most common tumor types profiled include non-small cell lung cancer (14.7\%), ovarian surface epithelial carcinomas (12.0\%), and colorectal carcinoma (11.4\%). This distribution partially reflects the global distribution of new cancer cases (per year) and partly the map of unmet clinical needs with respect to tumor type. For example, consistent with Figure 2, it has been shown that the most commonly diagnosed new cancers (excluding non-melanoma skin cancer) include lung (13.0\%), breast (11.9\%) and colorectal (9.7\%) cancer $^{26}$. For some tumor types, however, discordance between their distribution in the CMI database and their distribution in newly diagnosed cases is noted. For example, prostate cancer constitutes only $1.2 \%$ of all CMI MMP-tested cases but represents $7.9 \%$ of all new cases worldwide (out of all patients, males and females); whereas ovarian cancer constitutes $12.0 \%$ of all CMI MMP-tested cases, but represents only $1.7 \%$ of all newly diagnosed cases globally (out of all patients, males and females) $)^{26,27}$.

\section{Implementing MMP in Clinical Practice}

Although the MMP-guided treatment approach (when MMP is performed commercially or through academic centers) has been increasingly used in clinical practice, several barriers impede its implementation. These include the cost of MMP tests, but also the cost of the drugs recommended by the analysis (particularly if it involves their off-label use which may not be reimbursed). Notably, often, the MMP recommends conventional chemotherapy agents, which are relatively inexpensive (compared to targeted therapies) and mainly generic, so in such cases better selection is not associated with increased cost. Off-label use of therapies, could, however, also cause a regulatory challenge (depending on the regulations and health-care system in each country). Another important challenge is tissue procurement, as sufficient quantity of tumor sample which is representative and well-preserved is key for obtaining accurate/meaningful MMP results. Compromised tissue quality could lead to lack of results (because the respective test cannot be performed). To address this challenge, tissue procurement guidelines have been suggested including, for example, a recommendation for tissue stabilization within 20 minutes from excision ${ }^{28,29}$.

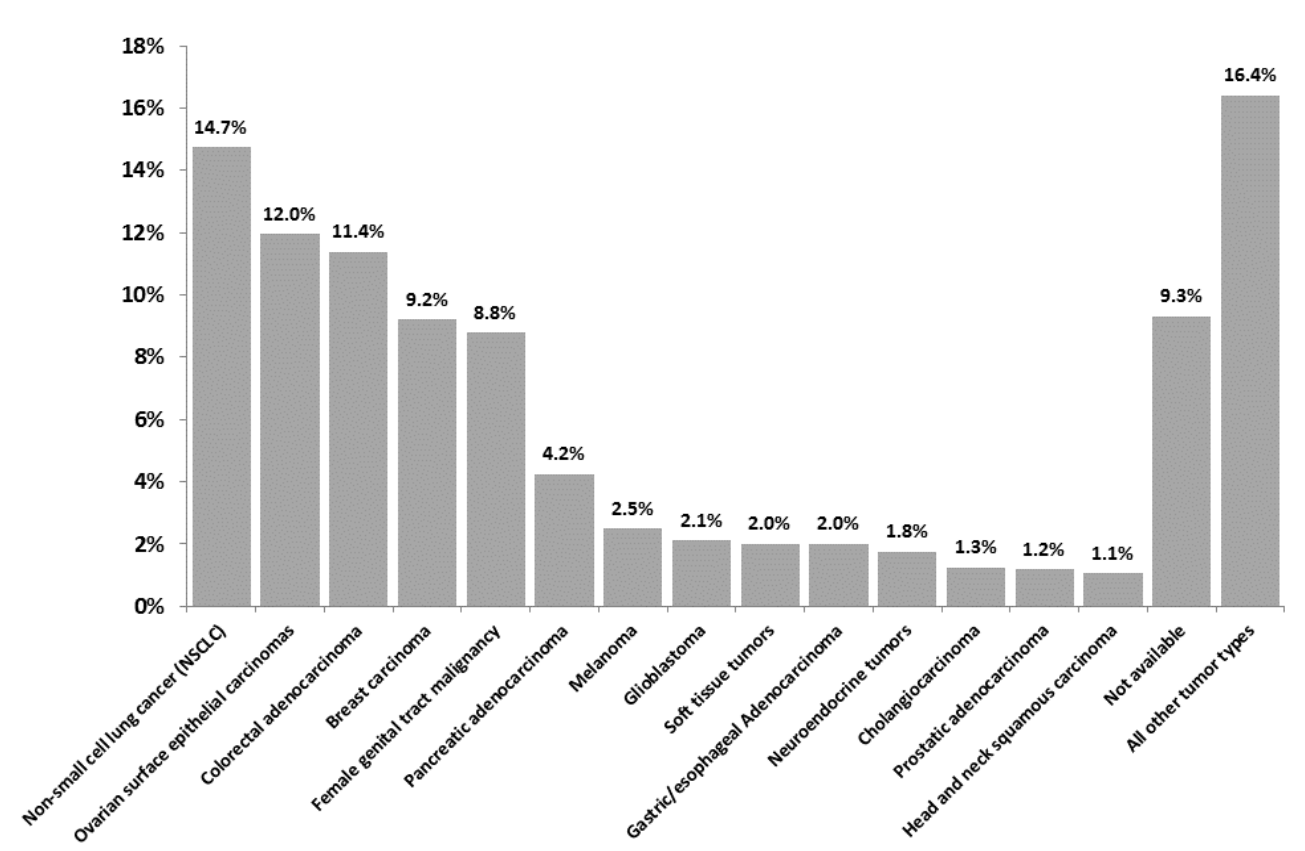

Figure 2: Distribution of tumor types in patients undergoing CMI MMP (as of June 2018, $N=156,458$, A. Voss, personal communication). All tumor types with $\geq 1 \%$ representation are included in the graph. Additional tumor types with representation between $0.1 \%$ and $1 \%$ included (by order of occurrence from high to low), lung small cell cancer, bladder cancer, small intestinal malignancies, liver hepatocellular carcinoma, non-epithelial ovarian cancer, kidney cancer, gastrointestinal stromal tumors, lymphoma, thyroid carcinoma, low grade glioma, retroperitoneal/peritoneal sarcoma, cancer of unknown primary, extrahepatic bile duct adenocarcinoma, uveal melanoma, thymic carcinoma, male genital tract malignancy, and lung bronchioloalveolar carcinoma. 
Devices to procure sufficient tissue without increasing the risk of biopsies have recently become available ${ }^{30}$.

The MMP studies suggest that patients may benefit from employing MMP in earlier lines when their performance status (PS) is good and they can still receive additional treatment. Ten of the 11 CMI MMP studies reported also on patients who could not proceed to receiving MMPguided treatment due to PS decline, disease worsening, or death ${ }^{13-18,20-23}$. These cases ranged from $5 \%$ to $24 \%$ of the patients who underwent MMP ${ }^{15-20,22-25}$.

The CMI MMP studies also provide anecdotal evidence that when using data from one MMP to guide multiple lines of treatments or in a patient with several metastases, tumor heterogeneity may become an issue. For example, Purim et al reported on 3 cases where the original HER2 result (from the original pathology report) and the HER2 result obtained through the MMP were discordant (in 2 of these cases the original testing was on the primary tumor and the second testing was on a metastases ${ }^{14}$. Thus, when using MMP in multiple lines, it may be beneficial to re-test to account for evolving tumor biology.

\section{Future Directions}

Several lines of research and development are essential for the MMP approach to further improve its clinical utility. In order for the MMP to keep its relevance, constant update in technologies and algorithms used is required to incorporate new findings on predictive biomarkers. For example, it is essential to perform profiling relevant to novel immunotherapies such as testing for the protein biomarker PDL-1, testing microsatellite instability (MSI) (DNA-based analysis), or IHC for MMR proteins, as well as testing for tumor mutation burden (TMB). In addition, efforts should be made to generate prospective data, as the current evidence includes mainly retrospective data.

\section{Conclusions}

MMP-guided therapy is a robust tool whose implementation is feasible in the community. This approach personalizes treatment, including that of chemotherapy, increasing the likelihood of response and sparing patients from unnecessary toxicity. Specifically, MMP provides the ability to tailor therapy to patients in later lines, particularly for patients who have already failed multiple lines of therapy and exhausted the standard therapy options (by suggesting therapies which may be used off-label). Using this approach has been shown to favorably impact PFS and OS. Additional prospective studies are warranted to further strengthen the evidence.

\section{Funding information}

Medical writing support was provided by Avital BareketSamish, $\mathrm{PhD}$, and was funded by Caris Life Sciences.

\section{Conflict of interest}

Dr. Purim reports serving in a consultant role with Caris Life Sciences. The other authors indicate no potential conflict of interest.

\section{References}

1. Joo WD, Visintin I, Mor G. Targeted cancer therapy--are the days of systemic chemotherapy numbered? Maturitas. 2013; 76(4): 308-14.

2. Trastuzumab [Package Insert]. South San Francisco, CA: Genentech Inc; 2017.

3. Cetuximab [Package Insert]. Indianapolis, IN; Eli Lilly and Company; 2018.

4. Von Hoff DD, Ervin T, Arena FP, et al. Increased survival in pancreatic cancer with nab-paclitaxel plus gemcitabine. N Engl J Med. 2013; 369(18): 1691-1703.

5. Teague A, Lim KH, Wang Gillam A. Advanced pancreatic adenocarcinoma: a review of current treatment strategies and developing therapies. Ther Adv Med Oncol. 2015; 7(2): 68-84.

6. Ehrlich Y, Margel D, Lubin MA, et al. Advances in the treatment of testicular cancer. Transl Androl Urol. 2015; 4(3): 381-90.

7. Culine S, Kerbrat P, Kramar A, et al. Refining the optimal chemotherapy regimen for good-risk metastatic nonseminomatous germ-cell tumors: a randomized trial of the Genito-Urinary Group of the French Federation of Cancer Centers (GETUG T93BP). Ann Oncol. 2007; 18(5): 917-24.

8. Bailey $\mathrm{CH}$, Jameson G, Sima C, et al. Progression-free survival decreases with each subsequent therapy in patients presenting for phase I clinical trials. J Cancer. 2012; 3: 7-13.

9. Slamon DJ, Leyland-Jones B, Shak S, et al. Use of chemotherapy plus a monoclonal antibody against HER2 for metastatic breast cancer that overexpresses HER2. N Engl J Med. 2001; 344(11): 783-92.

10. Slamon D, Eiermann W, Robert N, et al. Adjuvant trastuzumab in HER2-positive breast cancer. N Engl J Med. 2011; 365(14): 1273-83.

11. Romond EH, Perez EA, Bryant J, et al. Trastuzumab plus adjuvant chemotherapy for operable HER2-positive breast cancer. N Engl J Med. 2005; 353(16): 1673-84.

12. Olmos D, A'Hern RP, Marsoni S, et al. Patient selection for oncology phase I trials: a multi-institutional study of prognostic factors. J Clin Oncol. 2012; 30(9): 996-1004.

13. Von Hoff DD, Stephenson JJ, Jr., Rosen P, et al. Pilot study using molecular profiling of patients' tumors to find potential targets and select treatments for their refractory cancers. J Clin Oncol. 2010; 28(33): 4877-83.

14. Purim 0 , Beny $A$, Inbar $M$, et al. Biomarker-driven therapy in metastatic gastric and esophageal cancer: Real-life clinical experience. Target Oncol. 2018; 13(2): 217-26.

15. Epelbaum R, Shacham-Shmueli E, Klein B, et al. Molecular profilingselected therapy for treatment of advanced pancreaticobiliary cancer: A retrospective multicenter study. Biomed Res Int. 2015; 2015 : 681653.

16. Ramanathan RK, Weiss GJ, Posner RG, et al. A phase 2 trial of personalized cytotoxic therapybased on tumor immunohistochemistry in previously treated metastatic pancreatic cancer patients. J Gastrointest Oncol. 2017; 8(6): 925-35.

17. Jameson GS, Petricoin EF, Sachdev J, etal. A pilot study utilizing multi-omic molecular profiling to find potential targets and select individualized treatments for patients with previously treated metastatic breast cancer. Breast Cancer Res Treat. 2014; 147(3): 579-88. 
18. Popovtzer A, Sarfaty M, Limon D, et al. Metastatic salivary gland tumors: A single-center study demonstrating the feasibility and potential clinical benefit of molecular-profiling-guided therapy. Biomed Res Int. 2015; 2015: 614845

19. Dean A, Byrne A, Marinova M, et al. Clinical outcomes of patients with rare and heavily pretreated solid tumors treated according to the results of tumor molecular profiling. Biomed Res Int. 2016; 2016: 4627214.

20. El Nahas T. Multiplatform molecular profiling to determine treatment selection in rare, aggressive, refractory and metastatic cancers with limited treatment options. Paper presented at: ICACT 2017 - The 28th International Congress on Anti-Cancer Treatment; March 21-23, 2017; Paris, France.

21. El Ahmadie A, Ibrahim T, El Karak F, et al. Molecular Profiling guided treatment in refractory solid tumors: practical impact and clinical responses: Experience of a single center. Eur J Cancer. 2015; 51(Supplement S3) S43.

22. Chahine G NF, Saleh K et al. Clinical outcomes of patients with previously treated advanced or metastatic cancer before or after tumor profiling: results of a monocentric pilot study in Lebanon. Paper presented at: ICACT 2016 - The 27th International Congress on Anti-Cancer Treatment; February 2-4, 2016; Paris, France.

23. Seeber A, Gastl G, Ensinger C, et al. Treatment of patients with refractory metastatic cancer according to molecular profiling on tumor tissue in the clinical routine: an interim-analysis of the ONCOT-PROFILE project. Genes Cancer. 2016; 7(9-10): 301-8.

24. Marshall J, Schwartzberg LS, Bepler G, et al. Novel panomic validation of time to next treatment (TNT) as an effective surrogate outcome measure in 4,729 patients. J Clin Oncol. 2016; 34 (supplement):11521.

25. Spetzler D, Xiao N, Burnett K, et al. Multi-platform molecular profiling of 1,180 patients increase median overall survival and influences treatment decision in 53\% of cases. Eur J Cancer 2015; 51(Supplement S3): S44.

26. Torre LA, Bray F, Siegel RL, et al. Global cancer statistics, 2012. CA Cancer J Clin. 2015; 65(2): 87-108.

27. Ferlay J, Soerjomataram I, Dikshit R, et al. Cancer incidence and mortality worldwide: sources, methods and major patterns in GLOBOCAN 2012. Int J Cancer. 2015; 136(5): E359-386.

28. Hicks DG, Boyce BF. The challenge and importance of standardizing preanalytical variables in surgical pathology specimens for clinical care and translational research. Biotech Histochem. 2012; 87(1): 14-7.

29. Espina V, Mueller C. Reduction of preanalytical variability in specimen procurement for molecular profiling. Methods Mol Biol. 2012; 823: 49-57.

30. Lalji UC, Wildberger JE, Zur Hausen A, et al. CT-guided percutaneous transthoracic needle biopsies using 10G large-core needles: Initial experience. Cardiovasc Intervent Radiol. 2015; 38: 1603-10. 